\title{
THE MEANING OF WORK FOR THE PERSON WITH A STOMA ${ }^{1}$
}

\author{
Vanessa Cristina Mauricio², Norma Valéria Dantas de Oliveira Souza, Marcia Tereza Luz Lisboa ${ }^{4}$
}

${ }^{1}$ Article extracted from the dissertation - The person with a stoma and the process of inclusion in work: contribution to nursing, presented to the Postgraduate Program in Nursing at the Universidade do Estado do Rio de Janeiro (UERJ), in 2011.

2 Doctoral student on the Postgraduate Program in Nursing at the UERJ. Nurse of the Ministry of Health and the Guarus Hospital. Rio de Janeiro, Rio de Janeiro, Brazil. E-mail: vanessacmauricio@gmail.com

${ }^{3}$ Ph.D. in Nursing. Permanent professor of the Postgraduate Program in Nursing, ENF/UERJ. Rio de Janeiro, Rio de Janeiro, Brazil. E-mail: norval_souza@yahoo.com.br

${ }^{4}$ Ph.D. in Nursing. Associate professor of the Department of Basic Nursing, of the Anna Nery School of Nursing of the Universidade Federal do Rio de Janeiro. Rio de Janeiro, Rio de Janeiro, Brazil. E-mail: marcialis@terra.com.br

\begin{abstract}
The present qualitative and descriptive-exploratory study aims to focus on the meaning of work for 20 persons with stomas. Its objectives are: to identify the working situation of the people with stomas; and to analyze the work's meanings in their lives. It used semi-structured interviews for data collection in a Rehabilitation Institute in Rio de Janeiro and Thematic Content Analysis for data analysis. The results evidenced that the subjects present dialectical feelings in relation to the work, considering that work activity is a source of life, ensures material subsistence and signifies social participation. However, they also consider the work as a source of suffering, as they link it to a feeling of exclusion and to social segregation. It is concluded that work, in spite of raising negative feelings, is felt by the majority as something positive and that, because of this, nurses and other professionals from the area of healthcare and similar areas must encourage and viabilize the reinsertion of the person with a stoma into the world of work.
\end{abstract}

DESCRIPTORS: Occupational health. Surgical stomas. Disabled persons. Rehabilitation. Social security.

\section{O SENTIDO DO TRABALHO PARA O SER ESTOMIZADO}

RESUMO: A presente pesquisa, qualitativa e descritivo-exploratória, objetiva tratar do sentido do trabalho para vinte pessoas estomizadas. Os objetivos são: identificar a situação trabalhista dos estomizados; e analisar os significados do trabalho em suas vidas. Utilizou-se a entrevista semiestruturada para coleta de dados em um Instituto de reabilitação no Rio de Janeiro e a Análise Temática de Conteúdo para análise dos dados. Os resultados evidenciaram que os sujeitos apresentam sentimentos dialéticos em relação ao trabalho, considerando que a atividade laboral é fonte de vida, garante subsistência material e significa participação social. No entanto, também consideraram o trabalho como fonte de sofrimento, pois remetem ao sentimento de exclusão e segregação social. Conclui-se que o trabalho, apesar de aludir sentimentos negativos, é majoritariamente sentido como algo positivo e, por isso, os enfermeiros e demais profissionais da saúde e áreas afins, devem estimular e viabilizar a reinserção do estomizado no mundo laboral.

DESCRITORES: Saúde do trabalhador. Estomas cirúrgicos. Pessoas com deficiência. Reabilitação. Previdência social.

\section{EL SIGNIFICADO DEL TRABAJO PARA EL SER ESTOMIZADO}

RESUMEN: El objeto de esta investigación cualitativa y descriptiva exploratoria es abordar el significado del trabajo para veinte personas estomizadas, o sea, determinar la situación laboral de los estomizados y analizar los significados del trabajo en sus vidas. La entrevista semiestructurada recolectó datos en una institución de rehabilitación en Río de Janeiro y utilizó el Análisis Temático de Contenido para el análisis de datos. Los resultados mostraron que los sujetos exhiben sentimientos dialécticos respecto al trabajo, considerándose la actividad laboral como la fuente de vida que garantiza la subsistencia material y la participación activa en la sociedad, sin embargo, también es fuente de sufrimiento, debido al sentimiento de exclusión y segregación social. Se concluye que, aunque el trabajo alude a sentimientos negativo, es sentido como algo más positivo, razón por que los enfermeros, otros profesionales de la salud y afines deben alentar y facilitar la reintegración del estomizado en el mundo laboral.

DESCRIPTORES: Salud ocupacional. Estomas quirúrgicos. Personas con discapacidad. Rehabilitación. Seguridad social. 


\section{INTRODUCTION}

The interest in researching the meaning of work for the person with a stoma began during professional practice, when the importance was observed of inclusion in work for this clientele, which asked about the possibility of returning to work, in spite of the existence of the stoma resulting from a pathological process or from a serious accident in the body structure.

The presence of a stoma on a person's body results in numerous transformations, the most forceful of which is the loss of control over elimination, with the consequent use of the equipment for collecting feces and/or urine. Sphincter control is a condition judged to be essential for social coexistence, and the loss of this function can lead to the person to isolation, making them believe that they will not be able to return to the same activities exercised prior to the surgery. ${ }^{1-3}$

Inclusion in work is one of the key points of the process of rehabilitation of persons with disabilities, represented in this study by persons with stomas. Work makes the individual feel useful and socially integrated, this being fundamental for a better quality of life, in addition to contributing to the person's financial support and that of her family. It is unnecessary to add that in a capitalist society, such as in the Brazilian context, social inclusion is processed through work. ${ }^{4-6}$

Thus, for the person with a stoma, working can mean continuation of their life and the possibility of returning to the activities undertaken prior to the existence of the stoma, such as, for example, leisure and professional training, made viable by remunerated productive activity. However, being inserted in work activity can cause intense psychological suffering, as we live in a consumerist and technocratic world which, in addition to requiring multifunctionality from the workers and the maximization of profits, permeates an intense competitive activity between people, such that they may remain in the job market. ${ }^{7-8}$

It is in this complex work scenario that the person with the stoma tries to integrate. For this person, the difficulties found are even greater than for the other individuals, as persons with stomas, in addition to seeking inclusion in this adverse work scenario, also need to deal with alterations of body image and with changes in the functioning of the organism, which maximize the difficulties of inclusion or keeping oneself in the world of work.
According to the National Policy of Worker's Health and Safety, through the Professional Rehabilitation Program, any individual disabled through a work accident (as with her family members and people with disabilities) has the right to return to work full- or part-time, in activities which do not harm or worsen her health problem. As a result, there has to be constant inspection of the competent bodies, for continuous evaluation of these work environments and of the working conditions provided for the rehabilitated indi-

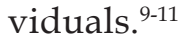

After selection of the study object, in January 2013, a bibliographic search was initiated for scientific productions linked to this health issue, in the Virtual Health Library, using the keywords: stomas/work and stomatherapy/work. As a result, 18 studies linked to the issue were found; however, these did not allude directly to the inclusion in the work of the person with a stoma, apart from the dissertation of the author of this study, which discusses the issue in question. Hence, due to the immense bibliographic gap, the interest in conducting this study intensified still further.

Based on this fact and on the contextualization elaborated regarding the object, it was decided to select the following objectives: to identify the working situation of persons with stomas; and to analyze the meanings of the work in their lives.

Thus, this study is intended to contribute as a source of data for research on this issue, and to contribute to the broadening of knowledge of nurses and other health professionals who work with this clientele. In addition to this, the intention is to offer support for professionals to undertake approaches which encourage and viabilize the inclusion of the person with the stoma in the world of work, within her limitations, also alerting family members and friends to the importance of work in these patients' lives.

\section{METHODOLOGY}

This is a descriptive-exploratory study, with a qualitative character, undertaken in the Instituto Municipal de Medicina Física e Reabilitação, located in Rio de Janeiro-RJ, which offers the Program for Care for the Person with a Stoma, representing an important center of attendance for this clientele. This institution dispenses stoma pouches and adjuvant equipment to the persons with stomas, and provides advice related to self-care, maintenance of independence and social inclusion. 
The study subjects are 20 persons with intestinal stomas, registered with the above-mentioned Program, aged between 35 and 62 years old, and who met the following inclusion criteria: to be aged between 18 and 65 years old; to have had a permanent intestinal or urinary stoma for over one year; to have worked at some point in their lives, regardless of whether they still undertake this activity or not; not to have complications preventing them from returning to work; and to show interest in participating in the study voluntarily.

Data collection was undertaken between January and March 2010, using an individual semi-structured interview, focusing on the meaning of work in these peoples' lives, recorded on a media player.

The study was submitted to the Research Ethics Committee of the Department of Health of the Prefecture of the Municipality of Rio de Janeiro, through which was obtained a favorable decision under n. 274 $/ 2009$. At the time of data collection, both the interviewees and the researchers signed the terms of consent. In addition to this, a code was defined containing the letter ' $i$ ' followed by a number corresponding to the order in which the interviews were held, which made it possible to ensure confidentiality regarding the identification of the study participants.

The data was analyzed through thematic content analysis, which gave rise to the following category of analysis: Work for the person with a stoma: dialectical meanings. This category contained 290 Record Units (RUs) and eight Units of Meaning.

\section{RESULTS AND DISCUSSION}

\section{Characterization of the study subjects}

It is relevant to present a brief characterization of the study subjects, as this will contribute to a broader analysis of the object.

In this regard, $55 \%$ (11) of the study subjects are women; age varied between 35 and 62 years old; $70 \%$ (14) of the study's clients were aged below 60 years old, indicating a change in this clientele's profile, with people receiving stomas at increasingly younger ages. This change in the age range of persons with stomas may indicate a greater desire on the part of patients to continue with their life plans and remain active and participative in society; this being the case, work represents a strong determi- nant for remaining active and socially embraced. ${ }^{12}$

Of the interviewees, $50 \%$ (10) had not finished junior high school, which reflects a low educational level among the majority of the subjects, leading them to occupations which require few qualifications, such as general services. Consequently, these individuals are poorly paid, and the majority (55\%) have a family income of between one and two minimum salaries. These poor financial conditions hinder the process of rehabilitation of persons with stomas, as the consequences can include difficulty in acquiring the stoma pouches and adjuvant equipment, when these are unavailable from the Unified Health System. In addition to this, on such a low salary band, these persons face difficulty in training to obtain a better profession so as to increase their income. ${ }^{13}$

Of the subjects, $70 \%$ (14) are married. The presence of the companion in the home can mean support for the client with a stoma, who feels more secure throughout the process of rehabilitation, without mentioning economic issues, as the spouses can share in the household expenditures. On the other hand, $15 \%$ (3) of the subjects stated that there was nobody else in their residence; hence, this number of subjects depends exclusively on their own benefits and/or work for their support and/or that of their family members.

Table 1, below, presents, in a systematized form, information regarding work activities which the subjects undertook prior to the existence of the stoma, and their current working condition.

In the case of the women, who form the majority of the interviewees (55\%), one can observe work directed towards activities which reproduce those undertaken in the home, such as cooks, maids, companions for elderly persons, hotel supervisors, and kitchen assistant, among others. These activities, besides being badly paid, are neither recognized nor valued socially, because they are associated with the female universe, submissive and inferior in the androcentric world. ${ }^{14}$

The men, on the other hand, exercise heavier work, considered masculine, such as builder, driver and watchman. Furthermore, the men had a higher educational level and undertook better paid activities, represented by the statistician and realtor. This fact is also similar to the findings of other studies, which revealed that women are poorly paid and work in activities which are poorly qualified and little recognized socially or financially. ${ }^{15}$ 
Table 1 - Working situation of the client with a stoma prior to and after the stoma. Rio de JaneiroRJ, Brazil, 2011

\begin{tabular}{|c|c|c|}
\hline Study subjects & Occupation prior to the stoma & Current employment situation \\
\hline i 1 & Inspector's assistant & Social security \\
\hline i 2 & Watchman & Retired due to disability \\
\hline i3 & Taxi driver & Retired due to disability and driver \\
\hline i 4 & Builder & Street vendor \\
\hline i 5 & Delivery sector & Retired due to disability \\
\hline i 6 & Textiles technician & Retired due to disability \\
\hline i 7 & Maid & Retired due to disability and irons clothes \\
\hline i 8 & Typist & Retired due to disability and embroiderer and crochet \\
\hline i 9 & Seamstress & Autonous saleswoman \\
\hline i 10 & Cook & Retired and craftswoman \\
\hline i 11 & Statistician & Retired and salesman \\
\hline i 12 & Shopkeeper & Sickness benefits and maid \\
\hline i 13 & Realtor & Realtor \\
\hline i 14 & Laundress & Sickness benefits and laundress \\
\hline i 15 & Companion for elderly persons & Retired due to disability and companion for elderly persons \\
\hline i 16 & Kitchen assistant & Retired due to disability and owner of small business \\
\hline i 17 & Driver and delivery man & Sickness benefits and office assistant \\
\hline i 18 & Maid & Sickness benefits and irons clothes \\
\hline i 19 & Hotel supervisor & Retired due to disability and companion for elderly persons \\
\hline i 20 & Builder's assistant & Sickness benefits \\
\hline
\end{tabular}

In relation to the current work situation, one may observe in table 1 a large number of subjects who still work $(75 \%)$, whether they are retired to disability or receiving sickness benefits. Under labor laws, those who are retired due to disability may not return to work; however, one may perceive that the subjects do so due to the financial necessity of adding to the family income, and due to the well-being caused by having a social occupation considered essential, as is the case with work activities.

In accordance with Table 1, it stands out that among the three subjects who work and do not receive benefits, only one (5\%) is inserted in the formal labor market (realtor), with an employment record book in use and his labor rights guaranteed. Thus, the subjects' current occupations evidence their low educational level, which hinders their inclusion in the world of work, causing them to work informally in order to add to their income.

The length of time the persons had had the stoma varied between one year (the shortest period of time allowed for the person to be a subject in this study) and 24 years; the main reason which led to the construction of the stoma was colorectal cancer $(55 \%)$. The presence of complications in the stoma affected $35 \%$ (7) of the clients at some point, with emphasis being placed on irritation of the peri-stomal skin (30\%). These complications were not present at the time of the interviews, and therefore did not characterize limiting factors for inclusion in the world of work at the time of data collection.

\section{Work for the being with a stoma: dialectical meanings}

In relation to the current work situation of the research subjects, $75 \%$ (15) continue to undertake some form of work activity; among these, only $15 \%$ (3) were not retired due to disability or receiving sickness benefits. The accounts of those who were inserted in the world of work, while not receiving help from the government, are evidenced by the following: I work selling sweets, and recently I haven't been receiving any form of help until now, no [...] (e 4); [...] I work as a realtor, I have my own company and I continue working as normal, I'm not retired yet [...] (i13).

These three subjects who were working without receiving benefits had been living for at least seven years with the stoma, which they had acquired while still young, which intensified in them the desire to remain inserted and participative in the world of work. In addition to this, there is the individual/subjective pleasure which these subjects can have through their productive 
activities, which characteristically lead them to interact with people and allow the exchanging of experiences. In this regard, such activities avoid segregation and isolation through the specific characteristics of the work task.

The other individuals who exercised some work activity received, as mentioned above, some benefits from the National Institute of Social Security (INSS, in Portuguese), whether this was the sickness benefits or the disability pension, as mentioned in some interviews: [...] I opened a luncheonette, where I work, because I can't work in a company because of my colostomy, and because I am retired [...] (i16); [...] I receive the sickness benefits and I do odd jobs from time to time as an office boy. Informally, I do something, but it's not a job as such, continuous, I can't work every day [...] (i17).

The accounts presented above evidence that, in spite of the persons with stomas receiving some sort of benefits from the government, the majority of them returns to work informally as, were this return to occur through formal employment, they would lose the benefits. Moreover, they return to work for financial and psychological reasons, as they cannot meet their needs and those of their families only with the money received from government benefits. ${ }^{16}$

In one study on the contributions to the working population made by the INSS, is is asserted that the governmental benefits cannot be considered generous; thus, in July 2003 “[...] $63.14 \%$ of the welfare benefits were equal to one minimum salary ( $46.32 \%$ of benefits in urban areas and $98.27 \%$ in rural areas), while the mean value of the benefits received was 1.74 minimum salaries (2.1 for urban areas and 1.01 for rural areas)" ${ }^{17: 1}$

Besides the financial issues, the subjects referred to the importance of the work as a source of pleasure and mental health, as, were they to remain at home, their thoughts would focus on the problem of their health, and, especially, on the stoma. When they think about the existence of the stoma, they associate it with isolation, feelings of uselessness, and inability to control elimination, among other thoughts which are harmful to their health. This being the case, work serves as a strategy for alienation of the health problems and the socio-emotional problems which originate based on the stoma.

The importance of work in the life of a person with some special need is essential, as it promotes feelings of usefulness, recognition and valorization, bringing both social and psycholog- ical well-being. In addition to this, individuals who have a disability but are inserted in the world of work have a positive feeling which is specific to their situation, which is that they are contributing to minimizing or deconstructing the social stigma and prejudice related to the disease or to the disability itself. These people also record other important feelings, of autonomy and independence, reconquering their participation in the world of work. ${ }^{18}$

As a consequence, not being able to work is associated with feelings of dejection, sadness and abandonment, evidencing that work is an important factor for people, as it ensures material subsistence, the feeling of belonging to a group, of being a productive and useful being, and of constructing and reconstructing peoples' identity and subjectivity. ${ }^{8}$

The accounts shown below characterize the sadness and the dejection of some subjects, through the lack of a job: [...] I haven't worked for some time, but I really want to get myself a job, I think I would be happy [...] (i1); [...] Not going back to work is not preferable, because it is not what we want, not me, not for anybody, but what can I do - I can't work [...] (i5).

All of these subjects desire to return to the world of work, but, for various reasons, remain away from working life. The employers see people with special needs - including those with stomas - as unable to return to work, which leads the latter to have feelings of uselessness and sadness. The creation of social movements which publicize issues to do with the being with a stoma and the world of work, creating new alternatives for social inclusion, is of extreme importance. ${ }^{16,19}$

The analysis of the interviews also evidences that the meaning of the work for the subjects is associated with positive and negative feelings, demonstrating the dialectic existent in relation to the meanings of work. Various authors who study the world of work mentioned this dialectic relationship of the work with the world of work: sometimes of the work creates pleasure, because it allows creation, financial support, and autonomy and recognition; and at other times it causes suffering, because the fear of unemployment, of competitiveness, and of stigmatizing judgement, and power relationships are also embedded in this world..$^{8,10-11,20}$ As a result, these contradictions were found in the subjects' discourses, in which the work has the meaning of material subsistence, of usefulness, of valorization and of life, but - in 
contrast - also means rejection and limitation, suffering and pain, mainly due to the impotence of not being able to achieve specific tasks.

Positive feelings in relation to returning to work were found in 17 accounts (53 RUs). These positive feelings were related to the well-being generated by the work, to the personal satisfaction, to the occupation of the mind and to the social reintegration. This is because, according to the subjects, working stops them from thinking about the difficulties experienced with the cancer and with the construction of the stoma; as may be observed in the following accounts: [...] If I were to stay without working, my mind would be in a bad way because of what I've gone through, with the operation [...] (i10); [...] When those of us with colostomies stay stuck at home, the world stops, it seems like everything is lifeless! I think that going back to work is a big deal [...] (i8).

In one study on the meaning of work for people with and without physical disabilities, it was ascertained that the positive aspects related to the work are centered on personal organization, social relationships, finances, professional valorization, citizenship, the conciliation of interests, autonomy and participation. It is possible to compare these results with those of the present study, in relation to the reasons which please and give pleasure to the subjects in relation to the maintenance of work activities. $^{4}$

In the three interviews which did not directly mention the positive aspects mentioned previously in relation to work, there are references to the importance of work in aspects such as being a source of income and usefulness. It is not surprising, therefore, that work, meaning a guarantee of material subsistence, is mentioned by 10 subjects (32 RUs).

It is interesting to analyze that, among the 10 reports gathered which emphasize the meaning and the value of work as a guarantee of income, three are represented by subjects who survive only on government benefits, which indicates - once again - how meager these benefits are, and the extent to which they do not cover the subjects' material needs. In one study undertaken regarding the difficulties of social inclusion for people with disabilities, this analysis is reinforced, when the authors assert that those with stomas seek to complement their income, due to the immediate need for supply with basic needs, collective equipment, medications, incontinence pads and other adjuvant materials for self-care. ${ }^{10}$
The work as signifying life and usefulness was mentioned by 11 subjects (22 RUs), which associated the work with the fact of being alive, active and having survived the adverse and serious situations, such as cancer: [...] It has meaning, the work keeps me alive [...] (i3); [...] work is the continuation of life because if we give up, in terms of the illness, we are done for [...] (i11).

Work is viewed, by these subjects, as a continuation of life, as our society links work with survival and with the possibility of having a social and personal identity, of having purchasing power and the power to consume, and being able to live comfortably. It is possible to confirm this fact, as many individuals, on retiring, correlate this period with the end of their lives. In modern society, work is viewed as a centrality, that is, it comes to signify life itself, being seen as that which gives meaning to peoples' existence. ${ }^{21}$

The negative feelings in relation to work, which were found in 11 interviews and which included 51 RUs, mentioned the lack of jobs and opportunities for persons with stomas; the difficulties in the relationships between employees and employers; and of the psychological difficulties, which involve the fear of the exposure of their body. Besides these aspects, the subjects mentioned the physical limitations related to the loss of sphincter control: [...] the difficulty in working is the relationship between boss and employee. There are things which - unfortunately - you can't explain and change, unfortunately [...] (i11); [...] because not everybody accepts this! Who is going to accept an organ which left its place and went to another place, and who knows that you are going to be touching it, who will feel relaxed in your presence? Nobody [...] (i15).

The negative feelings in relation to the worker were associated mainly with the difficulties which the subjects present in returning to a working life. These difficulties, of various natures, cause feelings of distress and even anger to emerge. People with stomas have difficulty getting to work; obstacles in the changing of the collecting equipment, and due to the inadequate conditions in the toilets; difficulties due to work colleagues finding their constant trips to the bathroom strange. Summarizing, these people face many difficulties and, because of this, some prefer to remain in isolation and give up working, causing sadness, exasperation, anger and denial, among other feelings which are harmful to health.

Rejection at work and the fear of prejudice are constant fears in the life of the person with 
the stoma, being referred to in ten interviews (18 RUs). The following reports evidence this: [...] I could return to work, but I want to avoid the problem with the others who are not like me [...] (i6); [...] because not everybody accepts working with a person with a stoma, and I am tired of seeing people who don't accept it [...] (i12).

The negative feelings aroused in people with stomas in relation to work, the difficulties in the interpersonal relationships and the physical and emotional strain are mentioned as major obstacles, as society often ends up excluding the person with a disability from the labor market. However, this situation is considered a paradox, a misconception, as the government encourages business people and managers to employ people with disabilities, exempting them with discounts on taxes, instituting quotas in examinations for public-sector employment* for individuals with special needs/disabilities, but does not develop and implement strategies such that these subjects may feel themselves to be truly included. ${ }^{4,10}$

Thus, there is no adaptation in the infrastructure of the work environment to receive the people with disabilities, and there is no program or encouragement training them for a new work activity which is in consonance with their new health conditions. Furthermore, one does not observe educational campaigns which de-construct and/or minimize the social stigma and prejudices linked to those with disabilities, allowing the genuine embracement of these people. In this regard, what appears in those with stomas are dialectical feelings in relation to the meaning of the work, as the same must be seen as something positive - but - lacking the biopsychosocial conditions allowing inclusion with dignity in the world of work, becomes a source of suffering.

It stands out that the nurses and other professionals from the areas of health and similar areas involved with the process of rehabilitation of people with stomas should have knowledge regarding the work activities indicated for this clientele and, in this way, guide them in respect of their rights to be included in work, encouraging them to re-enter the world of work. ${ }^{16}$ The constant support of the health team and family members for persons with stomas becomes essential in overcoming the difficulties found in the social and work environments.

\section{CONCLUSIONS}

The study's results cover the research's objectives, assisting with knowledge regarding the work situation of the clientele with stomas, before and after the surgery which resulted in the stoma; and with the signification of the work in their lives, demonstrating the importance of inclusion in work for the rehabilitation process of persons with stomas.

When the study was started, there was a certain concern as to whether persons with stomas would be found who were included in the world of work, as, in addition to not having found many scientific studies in the area, there was the idea that many of these subjects might be "hiding behind" their disability, through fear, shame and prejudice, preferring to live in isolation from society, receiving only government benefits. However, on entering the study field, it was ascertained that many subjects were working, as that they considered productive activity to be relevant not only to social inclusion but also to their survival.

The subjects' characterization demonstrates some factors which predispose to and promote the return to work, such as the young age of those with stomas; the presence of family support; and the need to add to the family income, due to low salaries and to the new health needs of individuals, such as acquiring collective and adjuvant equipment. The low educational level and low level of professional qualification, on the other hand, become obstacles to returning to work.

When those with stomas succeed in insertion in employment, it occurs informally, in occupations which are different from those held previously, and which lack worker's rights, it being common to receive government benefits concomitantly with informal work, which is an illegal situation.

The dialectic in relation to work was shown to be present in various points of the analysis, as work signifies, at the same time, something positive and negative in the subjects' lives. The positive meanings of work are mainly linked to the increase in income and to psychological and social well-being resulting from the work activities, as the work activity leads the individuals to feel useful, alive and included, thus being characterized as an important element of the rehabilitation process.

* In Brazil, one gains employment in state-run organizations such as public hospitals or the Civil Service by sitting a competitive examination. Translators note. 
The negativity referent to the work is related to the difficulty of acquiring employment and to the acceptance of the person with the stoma in the workplace by the employers and by other workers, as the ignorance of the pathology and of these individuals' needs on the part of the work collective can lead to stigma and rejection in the group. Other important factors which can impede reinsertion in the world of work are the physical barriers and the work environment which is not suited to the person's health conditions.

In this perspective, it is necessary to sensitize and guide society in relation to what it is to be a person with a stoma, emphasizing their strengths and limitations, sensitizing employers and co-workers regarding the importance of inclusion at work, as the presence of the stoma, on most occasions, does not impede the individuals' return to a working life. Such a measure would impact on the well-being of persons with stomas and contribute to minimizing prejudice and stigma regarding individuals with special needs.

In addition to this, the training of health professionals, in particular nurses, due to their close relationship with the clientele assisted, is suggested, with the aim of making them understand not only the complexity of the biopsychosocial changes which affect persons with stomas, but also the possibilities and the legal rights which these people have already conquered and which may promote their reinsertion in work. Once one understands this complex universe, it is possible to advise and encourage this population to return to work. It is noteworthy that specialized training in stomatherapy in Brazil is continuously growing, and offers the nurses an important theoretical and practical framework for working with clients with stomas, favoring a holistic and comprehensive view of the same.

It is also suggested that nurses should function in the aspects which results in suffering related to insertion in work, such as, for example, the physical structure of the places which are proposed to employ those with stomas. It is also necessary to sensitize the work collective regarding the constant visits to the toilet and the need to train persons with stomas for work tasks which are different from those which they undertook prior to the existence of the stoma. For this, it must be understood that the nurses, due to being excellent educators, perform an important role in achieving these measures. The State, in its turn, must comply with the legal aspects conquered by people with special needs, knowing how to evaluate - through its experts from Social Security and the Worker's Health Services - the specific characteristics of individuals with stomas, referring them appropriately for re-training or to receive government benefits, when they are considered unable to return to work.

Also suggested is the development of further studies linked to this issue, so as to produce knowledge which, ultimately, results in comprehensive and more qualified care for the person with a stoma, promoting a greater socialization of these peoples' difficulties. It is emphasized that the professional organizations of numerous professions/ occupations must recognize the specific characteristics of persons with stomas and the importance of the process of rehabilitation in work, assisting in the continuous struggle for social inclusion, taking into account the biopsychosocial limitations of each individual.

\section{REFERENCES}

1. Pittman J. Characteristics of the patient with an ostomy. J Wound Ostomy Continence Nurs. 2011 MaI-Jun; 38(3):271-9.

2. Nascimento CMS, Trindade GLB, Luz MHBA, Santiago RF. Vivência do paciente estomizado: uma contribuição para a assistência de enfermagem. Texto Contexto Enferm. 2011 Jul-Set; 20(3):557-64.

3. Nybaek H, Knudsen DB, Laursen TN, Karlsmark $\mathrm{T}$, Jemec GBE. Quality of life assessment among patients with peristomal skin desease. Eur J Gastroenterology Hepatol. 2010 Fev; 22(2):134-43.

4. Pereira CS, Prette AD, Prette AA. Qual o significado do trabalho para as pessoas com e sem deficiência física? Rev Psico USF. 2008 Jan-Jun; 13(1):105-14.

5. Wagner J. Os cenários do trabalho no Brasil. Texto Contexto Enferm. 2003 Out; 12(4):451-60.

6. Silva NG, Gama FA, Dutra RA. Percepção de pacientes com estomia sobre mitos e medos relacionados a esta condição. Rev Estima. 2008 JanMar; 6(1):22-6.

7. Navarro VL, Padilha V. Dilemas do trabalho no capitalismo contemporâneo. Psicol Soc. 2007; 19(esp):14-20.

8. Antunes R. Os sentidos do trabalho: ensaios sobre a afirmação e a negação do trabalho. São Paulo (SP): Boitempo; 2009.

9. Ministério da Saúde (BR). Política Nacional de Segurança e Saúde do Trabalhador. Brasília (DF): MS; 2004.

10. Oliveira JM, Araújo JNG, Romagnoli RC. Dificuldades relativas à inclusão social das pessoas com deficiência no mercado de trabalho. Lat Am J Fundam Psychopathol. 2006 Mai; 6(1):77-89. 
11. Rebelo P. A pessoa com deficiência e o trabalho. Rio de Janeiro (RJ): Qualitymark; 2008.

12. Associação Brasileira dos Ostomizados (ABRASO). Ostomias originadas por trauma. Rev Abraso. 2007; 8(1):12-14.

13. Luz MHBA, Andrade DS, Amaral HO, Bezerra SMG, Benício CDAV, Leal ACA. Caracterização dos pacientes submetidos a estomas intestinais em um hospital público de Teresina- PI. Texto Contexto Enferm. 2009 Jan-Mar; 18(1):140-6.

14. Oliveira D. O estigma da marca corporal invisível: estudo sobre o mundo do trabalho das pessoas com estomia intestinal definitiva [tese]. Brasília (DF): Universidade de Brasília. Programa de PósGraduação em Ciências Humanas; 2007.

15. Guedes MC, Araújo C. Desigualdades de gênero, família e trabalho: mudanças e permanências no cenário brasileiro. Rev Gênero. 2011 Jul-Dez; 12(1):61-79.

16. Mauricio VC, Souza NVDO, Lisboa MTL. O enfermeiro e sua participação no processo de reabilitação da pessoa com estoma. Esc Anna Nery Rev Enferm. 2013 Jul-Set; 17(3):416-22.
17. Fernandes R, Narita RDT. Contribuição ao INSS: equilíbrio financeiro e imposto sobre o trabalho. Escola de Administração Fazendária [online]. 2003 [acesso 2010 Out 8]. Disponível em: http://www. anpec.org.br/encontro2005/artigos/A05A055

18. Nohara JJ, Acevedo CR, Fiametti M. A vida no trabalho: as representações sociais das pessoas com deficiência. In: Carvalho-Freitas MN, Marques AL, organizadoras. Trabalho e Pessoas com Deficiência: pesquisas, práticas e instrumentos de diagnóstico. Curitiba (PR): Juruá; 2009. p. 71-88.

19. Souza MPD, Santos VR, Vilela BS, Paula MAB. Estoma e vida laborativa. Rev Estima. 2007 Jan-Mar; 5(1):13-20.

20. Antunes R. Adeus ao trabalho? Ensaios sobre as metamorfoses e a centralidade do mundo do trabalho. São Paulo (SP): Cortez; 2008.

21. Carvalho-Freitas MN, Marques AL. Satisfação das pessoas com deficiência no trabalho. In: CarvalhoFreitas MN, Marques AL, organizadoras. Trabalho e Pessoas com Deficiência: pesquisas, práticas e instrumentos de diagnóstico. Curitiba (PR): Juruá; 2009. p. 265-78. 